\title{
Brício de Abreu e o jornal literário Dom Casmurro*
}

\author{
Brício de Abreu and the \\ literary journal Dom Casmurro
}

TANIA REGINA DE LUCA

Professora Livre-Docente do Departamento de História Universidade Estadual Paulista "Júlio de Mesquita Filho" Pesquisadora do CNPq tania.luca@pq.cnpq.br

RESUMO O objetivo desse artigo é analisar, ainda de maneira preliminar, o jornal literário Dom Casmurro, que circulou entre 1937 e 1946 na cidade do Rio de Janeiro. Apresentam-se os responsáveis, objetivos e principais características do periódico, bem como sua trajetória, que conheceu significativa inflexão a partir de 1942. Pretende-se evidenciar a importância da publicação para a compreensão de aspectos do mundo da cultura e da história da imprensa, no referido período.

Palavras-chave Dom Casmurro, Brício de Abreu, história da imprensa

ABSTRACT This paper analyses, in a preliminary way, the literary newspaper Dom Casmurro, published between 1937 and 1946, in Rio de Janeiro. We present the writers responsible for the project, objectives, the main features of the publication and its trajectory, which experienced significant change 
from 1942 onwards. On the other hand, it is also possible to interrogate about the role played by Dom Casmurro regarding aspects of the culture and history of the press, during the period of circulation.

Keywords Dom Casmurro, Brício de Abreu, history of the press

\section{Introdução}

Em 13 de maio de 1937, veio a público o primeiro número de Dom Casmurro, que tinha à frente os gaúchos, então radicados no Rio de Janeiro, Brício de Abreu, diretor e proprietário, e Álvaro Moreyra, redator chefe. A fundação de mais uma folha na capital da República não se constituía propriamente numa novidade, entretanto o que particularizava esta empreitada era o fato de se tratar de um jornal (e não de revista) semanal, em formato grande (41 por $58 \mathrm{~cm}$ ), dedicado às questões literárias e culturais e escrito por intelectuais. A publicação circulou até dezembro de 1946 num total de 452 exemplares.

A breve descrição coloca para o pesquisador, de imediato, um conjunto de questões: quem eram os responsáveis e que lugar ocupavam no mundo letrado; como conceberam o projeto gráfico e editorial; quais as razões da longevidade do hebdomadário que circulou, sem interrupções, por nove anos; que tipo de alterações/transformações conheceu ao longo do tempo; quem eram seus principais colaboradores; como se relacionou com os órgãos de controle da informação do Brasil de Getúlio Vargas; de que maneira respondeu aos desafios do seu tempo, marcado pela presença de regimes de força, que se imiscuíam na produção cultural, e pelo desenrolar da Segunda Guerra Mundial. As indagações poderiam ser multiplicadas e a intenção desse texto é ensaiar alguns caminhos para começar a respondê-las.

\section{Idealizadores e objetivos}

As notas biográficas sobre Luís Leopoldo Brício de Abreu, bastante escassas, apresentam-no como jornalista, com intensa atuação na imprensa - colaborou em O País, Boa Noite, A Razão, A Tribuna, Diário da Noite, O Jornal, O Cruzeiro e fundou o jornal Dom Casmurro e Comoedia, revista mensal de teatro, música, cinema e rádio (1946-1950). A estréia literária ocorreu em 1919, com a peça Experiência, gênero que praticou ao longo da vida. ${ }^{1}$ Escreveu poesia (Evangelho de ternura, 1921), novela (A mais forte,

1 FISCHER, Antenor. A literatura dramática no Rio Grande do Sul (1900 a 1950). Porto Alegre: Pontifícia Universidade Católica do Rio Grande do Sul, 2007. (Letras, Tese de doutorado), v.2, p.172, listou vinte e uma peças de Brício e precisou a data de escritura e/ou representação de seis delas. 
1922), estudos de cunho biográfico (Eleonora Duse no Rio de Janeiro, 1958, Esses populares tão desconhecidos, 1963), traduziu dezenas de peças, além de haver atuado no rádio e na televisão. Há unanimidade em relação à data de nascimento (1903), mas a de morte oscila entre 1968 e 1970, dependendo da fonte consultada. ${ }^{2}$ É curioso notar que são muito ligeiras as menções à sua estadia em Paris, experiência por ele referida em vários dos textos publicados em periódicos. Moacir Werneck de Castro, em relato sobre viagem feita ao velho continente em 1935, na companhia do amigo Dante Viggiani, anotou:

Morava então em Paris o jornalista Brício de Abreu, ligado a Pierre Lazareff, diretor do influente Paris Soir. Amigo do pai de Dante, foi camarada conosco. De vez em quando nos levava a um café de Saint-Germain, promovendo um joguinho onde sempre conseguia ganhar, pelo menos para pagamento de despesas. De volta ao Brasil, mantinha um escritório na Cinelândia, abarrotado de livros franceses, de cujas editoras era representante. ${ }^{3}$

De fato, na porção do acervo Brício de Abreu depositado na Funarte, ${ }^{4}$ foi preservada carteira de identificação, expedida pelo Paris Soir e Paris Midi, datada de 1937, o que comprova sua relação com o periódico francês, mas não necessariamente indica que lá estivesse. Em função de suas colaborações na imprensa, foi obrigado a exilar-se durante o governo de Artur Bernardes, primeiro em Lisboa e depois, a partir de 1927, em Paris, ${ }^{5}$ de onde retornou ao Brasil em 1936 ou 1937, como se depreende dos agradecimentos dirigidos aos "companheiros de sempre, em Paris, durante quase dez anos", presentes no volume que reuniu textos escritos para Dom Casmurro entre 1937 e $1943 .{ }^{6}$ O projeto de fundar um jornal de divulgação cultural foi longamente acalentado e compartilhado com vários amigos brasileiros. ${ }^{7}$

A respeito de Álvaro Maria da Soledade Pinto da Fonseca Velhinho Rodrigues Moreira da Silva (1888-1964), seu companheiro de primeira hora, as informações são bem mais abundantes. Sabe-se que em 1910 deixou Rio

2 FISCHER, Antenor. A literatura dramática no Rio Grande do Sul, v.2, p.132, aponta o ano de 1970, tal como MENEZES, Raimundo. Dicionário literário brasileiro. 2 ed. Rio de Janeiro: Livros Técnicos e Científicos, 1978, p.6; enquanto COUTINHO, Afrânio e SOUSA, J. Galante de. Enciclopédia de literatura brasileira. Brasília: FAE, 1995, v.1, p.142, registra 1968.

3 CASTRO, Moacir Werneck de. Europa 1935: uma aventura de juventude. Rio de Janeiro: Record, 2000, p.98.

4 Brício doou à Fundação Biblioteca Nacional o que reuniu sobre música brasileira, seus autores e intérpretes, que contava várias centenas de fotos, algumas de cunho pessoal e do tempo de Dom Casmurro. Contudo, a documentação foi distribuída por diferentes instituições e as fotos alocadas nos acervos individuais dos artistas, o que comprometeu a integridade do conjunto.

5 Informação em ABREU, Brício. Nós. Montarroyos, meu amigo. Dom Casmurro, Rio de Janeiro, v.4, n.156, p.1, 06/07/1940. A informação sobre o exílio encontra-se em MENEZES, Raimundo. Dicionário literário brasileiro.

6 ABREU, Brício. De braços abertos para a França. Curitiba: Guaíra, 1943, p.8. Pierre Lazareff é mencionado juntamente com outros "queridos companheiros do Paris-Soir." Nos primeiros anos, o jornal de Brício trazia, com frequência, anúncios do congênere francês, cujo endereço no Brasil era o mesmo de Dom Casmurro.

7 ABREU, Brício. Nós. Dom Casmurro, Rio de Janeiro, v.1, n.1, p.1, 13/05/1937, afirma que discutiu a questão, em diferentes oportunidades, com Felipe d'Oliveira, Ronald de Carvalho, Paulo Duarte e Martins Fontes, sempre em Paris. 
Grande do Sul e instalou-se no Rio de Janeiro, onde se formou em Direito. Entretanto, ganhou notoriedade como poeta, vinculado aos simbolistas e à redação de Fon-Fon, ${ }^{8}$ e graças à intensa atuação no periodismo, sobretudo como cronista. ${ }^{9}$ Em 1918 assumiu a direção da sociedade anônima $O$ Malho, responsável pela edição de revistas como Para Todos e llustração Brasileira, que renovou juntamente com J. Carlos. Autor de várias peças, ${ }^{10}$ seu nome e o da esposa Eugenia (1898-1948) - mulher culta, das primeiras jornalistas do país, uma das fundadoras da União Feminina do Brasil, presa entre dezembro 1935 e fevereiro do ano seguinte, sob acusação de envolvimento com o Partido Comunista ${ }^{11}$ - estão associados às tentativas de renovação do palco com o seu Teatro de Brinquedo (1927) e a criação da Companhia de Arte Dramática (1937), apoiada financeiramente pelo Ministério da Educação e Saúde de Gustavo Capanema. ${ }^{12}$ A morada do casal tornou-se importante ponto de encontro de intelectuais residentes na capital ou de passagem pelo Rio de Janeiro. A partir dos anos 1940, Álvaro atuou de forma destacada no rádio e, em 1959, foi eleito para a Academia Brasileira de Letras.

Ao lançarem Dom Casmurro, Brício e Álvaro acumulavam larga atuação na imprensa além de manterem estreitas relações com o teatro. Os propósitos do novo periódico foram apresentados em suas respectivas colunas - Nós e Bom Dia! - que ocupavam a primeira página. O proprietário fez questão de frisar o distanciamento que o jornal guardaria das questões políticas ("não temos programa de política porque não acreditamos nela") e informou que o nome lhe ocorrera muitos anos antes, a partir da leitura de trechos de Le journalisme, de Mirbeau, numa noite parisiense, fria e brumosa, na companhia de amigos, entre os quais Felipe d'Oliveira. Naquela oportunidade, concluíram que somente um ranzinza, pouco afeito ao convívio social, um Dom Casmurro, poderia fazer algo semelhante em relação à imprensa carioca. Em 1937, o projeto finalmente concretizou-se e Brício esclareceu suas linhas mestras:

8 CASTRO, Moacir Werneck de. Europa 1935, p.25, reproduz avaliação de Luís Martins sobre o significado do escritor gaucho que "exercera para sua geração papel semelhante ao de Mallarmé para Gide, Claudel e Valéry...". ZILBERMAN, Regina. Álvaro Moreyra. 2 ed. Porto Alegre: Instituto Estadual do Livro, 1990, analisou a produção literária e organizou cronologia detalhada da vida e listagem das obras que publicou.

9 Seleção de crônicas e textos memorialísticos em: MOREYRA, Álvaro. Melhores crônicas de Álvaro Moreyra. São Paulo: Global, 2010 (seleção e prefácio de Mário Moreyra).

10 FISCHER, Antenor. A literatura dramática no Rio Grande do Sul, v.2, p.200-201, relaciona onze peças de Álvaro e fornece data da escritura e/ou representação de oito delas.

11 Sobre Eugenia, ver: SCHUMAHER, Schuma. Dicionário de mulheres do Brasil: de 1500 até a atualidade. Rio de Janeiro: Jorge Zahar, 2000, p.209-210. MOREYRA, Álvaro. As amargas, não... Lembranças. Rio de Janeiro: Lux, 1954, p.254-257, reproduz voto de pesar pela morte da esposa, consignado pela Câmara do Distrito Federal por iniciativa de Osório Borba, no qual se faz referência à sua atuação jornalística, teatral e política. Transcreveu, ainda, testemunho de Oswald de Andrade no Correio da Manhã, em que o escritor apontou o significado de Eugenia para sua geração.

12 Sobre a atividade do casal no teatro, ver: DÓRIA, Gustavo A. Moderno teatro brasileiro: crônica de suas raízes. Rio de Janeiro: SNT/MEC, 1975 e MAGALDI, Sábato. Panorama do teatro brasileiro. 2 ed. Rio de Janeiro: DAC/ Funarte, 1976. 
Dom Casmurro se propõe a suprir uma falha no Rio: - a de um jornal para todo mundo, feito por intelectuais e com um único propósito: evitar a burrice que por ai anda. Nada mais (...). Já sabemos que é uma audácia fundar um jornal que seja um canto para refúgio dos intelectuais, que perdendo o ar romântico e tuberculoso saibam se dirigir a todos os públicos. Não importa, com audácia ou sem ela aqui estamos e o público que nos julgue. ${ }^{13}$

Não era diversa a posição de Álvaro: "Dom Casmurro foi fundado por escritores e jornalistas e é dirigido por eles. Faz muito tempo que os aqui trabalham, trabalham para os outros... Agora não. Bom dia!"14 Em 1941, no número relativo ao quarto aniversário, o poeta esclareceu a origem da famosa epígrafe, extraída do romance de Machado de Assis e que sempre acompanhou a publicação. Reunidos em sua casa para tratar do futuro semanário, Brício insistia na necessidade de encontrarem uma frase para figurar ao lado do título e que resumisse o programa. Álvaro confidenciou que, naquela mesma noite, pôs-se a reler Dom Casmurro até se deparar com a passagem "A confusão era geral", que dava conta da situação reinante no momento da encomendação de Escobar: "Pronto. A epígrafe! Porque o jornal ia viver num tempo em que mesmo fora das casas com enterro a confusão era geral. Tão geral que não pode mais e caiu na guerra." ${ }^{15}$

\section{Dom Casmurro: caracterização}

Ao lado das declarações programáticas, é importante observar o jornal em si. A despeito do tipo de papel, formato e das sete colunas de textos, que normalmente compunham esse tipo de impresso, é muito provável que a distribuição do conteúdo chamasse a atenção do leitor. Em destaque, na parte superior direita da primeira página, eram listados os principais colaboradores do número e as temáticas abordadas, prática mantida até maio de 1938, quando o semanário comemorou seu primeiro ano de circulação (Figuras 1 e 2). Talvez animasse os responsáveis o desejo de chamar a atenção para a excelência do material ofertado a cada edição, o que inscrevia o semanário na tradição de algumas revistas literárias e culturais que, desde o século XIX, reservavam a quase totalidade da capa para o índice. Ao longo desse primeiro ano de circulação, raro foi o exemplar que não trouxe longa lista de nomes, que só cresceu com o correr do tempo, seguida da informação "e outros escrevem para Dom Casmurro". A estratégia, muito possivelmente, visava conferir legitimidade à folha, ao evidenciar que contava com o suporte de destacadas personalidades do mundo da cultura, ainda que nem todos tenham assinado,

13 ABREU, Brício de. Nós. Dom Casmurro, Rio de Janeiro, v.1, n.1, p.1, 13/05/1937.

14 MOREYRA, Álvaro. Bom dia! Dom Casmurro, Rio de Janeiro, v.1, n.1, p.1, 13/05/1937

15 MOREYRA, Álvaro. A confusão era geral. Dom Casmurro, Rio de Janeiro, v.5, n.199/200, p.1, 17/05/1941. Versão muito próxima encontra-se em MOREYRA, Álvaro. As amargas, não..., p.159-160, na qual o fato é datado de 1936. Caso a data esteja correta, Brício teria voltado ao Brasil antes de 1937. 
de fato, colaborações. Porém, a anuência para a menção pode ser lida como uma forma de apoio e, tal como a supressão, não é destituída de significado. ${ }^{16}$

Em Dom Casmurro foi constante a presença de autores estrangeiros, fosse com textos "especialmente escritos" para o jornal, como os editores faziam questão de assinalar, ou por meio de reprodução de material publicado em periódicos ou livros. A grande maioria era composta por franceses e nem sempre havia preocupação em levar a cabo a tradução para o português. De fato, ao longo dos seus nove anos de circulação, foram freqüentes as páginas em francês, o que deixa patente o tipo de público que se tinha em mira. A admiração de Brício pela cultura francesa e sua ligações com o hexágono eram evidenciadas na insistência em dar conta do cenário literário e artístico daquele país, nas referências explicitas, constantes em seus textos, e nas colaborações que obtinha para o jornal. A título de exemplo, pode-se citar saudação de Pierre Scize, publicada na edição inaugural, na qual o jornalista francês assumia a condição de padrinho da folha recém-nascida. ${ }^{17}$ Scize publicou várias colaborações no semanário, oportunidades em que era apresentado ao público como fundador de Dom Casmurro, seu diretor na Europa e redator do Paris Soir, não faltando mesmo superlativos como "o maior repórter do mundo". ${ }^{18}$ É certo que o início da guerra, e especialmente a queda da França, não poderia deixar de afetar tais intercâmbios.

Brício sempre esteve à frente do jornal, mas o mesmo não se pode dizer do conjunto da redação, que conheceu alterações significativas, conforme se observa na sistematização abaixo.

\section{Quadro 1}

Redação e administração de Dom Casmurro

\begin{tabular}{|l|l|l|}
\hline Cargo & Nome & Período (números) \\
\hline Diretor & Brício de Abreu & $01 / 452$ \\
\hline \multirow{3}{*}{ Redator chefe } & Álvaro Moreyra & $01 / 64$ e 149/231 \\
& Moacyr Deabreu & $07 / 14$ \\
& Marques Rebelo & $65 / 112$ \\
& Jorge Amado & $113 / 148$ \\
\hline
\end{tabular}

16 No primeiro número, havia trinta e oito nomes, entre os quais Afonso Arinos de Melo Franco, Carlos Drummond de Andrade, Cícero Dias, Érico Veríssimo, Gilberto Amado, Gilberto Freire, Graciliano Ramos, José Lins do Rego, Jorge de Lima, Lúcio Costa, Luiz Edmundo, Mário de Andrade, Marques Rebelo, Martins Fontes, Paulo Duarte, Prudente de Moraes Neto, Rodrigo Melo Franco de Andrade, Roquete Pinto, Rubem Braga e Sérgio Buarque de Holanda. Durante o primeiro ano de circulação, foi comum a incorporação de novos indivíduos e a exclusão de outros, valendo destacar que, no v.1, n.50, p.6, 12 mai. 1938, último a estampar a lista, estavam arrolados setenta e um nomes, entre os quais apenas duas mulheres: Adalgisa Nery, casada com Lourival Fontes, e Clara Torres. Aqui não se empreende o estudo sistemático dos componentes e do entra e sai que, articulado aos aspectos editoriais e de conteúdo, constitui-se em importante instrumento para a compreensão da trajetória do periódico.

17 SCIZE, Pierre. Discours pour un baptême. Dom Casmurro, Rio de Janeiro, v.1, n.1, p.2, 13/05/1937.

18 No v.1, n.22, p.12, 22/10/1937, anuncia-se, nos termos citados, o início da publicação da série "Os novos conquistadores, uma heróica aventura de um punhado de franceses na América do Sul", acompanhada de foto de Brício, Álvaro e Scize e de caricatura do trio, de autoria de Augusto Rodrigues. 


\begin{tabular}{|l|l|l|}
\hline Cargo & Nome & Período (números) \\
\hline \multirow{5}{*}{ Secretário da redação } & Joel Silveira & $18 / 169$ \\
& Omer Mont'Alegre & $18 / 57$ \\
& Oliveira e Franklin & $60 / 71$ \\
& Danilo Bastos & $72 / 169$ \\
& Clóvis de Gusmão & $168 / 235$ \\
\hline \multirow{5}{*}{ Gerente } & J. S. Lisboa & $01 / 03$ \\
& M. C. Cunha & $04 / 09$ \\
& M. Tunes & $10 / 14$ \\
& C. de Camargo de Almeida & $15 / 45$ \\
& Jorge Ramalho de Melo & $46 / 55$ \\
& Nogueira da Silva & $55 / 67$ \\
& Jorge Ramalho de Melo & $68 / 73$ \\
& Jorge Broca-Nera & $74 / 79$ \\
& Adenor Cabral & $98 / 135$ \\
& Nelson Nobre Alacid & $136 / 188$ \\
& Nael Fogueira & $189 / 270$ \\
& Leônidas Lacerda & $271 / 436$ \\
& Ari Gil & $437 / 452$ \\
\hline \multirow{2}{*}{ Chefe de publicidade } & Barbosa Thompson & 15 \\
& Godofredo Catramby & $111 / 121$ \\
& Alfredo Guimarães Dahlheim & $164 / 178$ \\
\hline
\end{tabular}

Os dados permitem afirmar que, com o correr do tempo, o grupo responsável pelo periódico minguou. Assim, a chefia da redação permaneceu vaga após o segundo afastamento de Álvaro Moreyra, em fins de 1941, o que também ocorreu com a secretaria logo no início do ano seguinte, frente à saída de Clóvis Gusmão. A publicidade, por seu turno, caracterizou-se pela falta de continuidade.

Aos cargos listados é preciso acrescentar dois conjuntos de redatores, os encarregados da iconografia (redatores desenhistas) ${ }^{19}$ e os que respondiam pelos textos, distinção esta mantida até janeiro de 1942, quando os primeiros deixaram de constar separadamente no expediente. Cabe ressaltar que sempre houve a preocupação de incorporar desenhos, mapas, reprodução de documentos, fotografias, charges e caricaturas às páginas do jornal, tal como ocorria na primeira delas, que invariavelmente trazia imagens, algumas produzidas com particular esmero (ver Figuras 3 e 4). Nos primeiros anos, no pé desta mesma página, figuravam as char-

19 Em maio de 1937, os redatores desenhistas eram Augusto Rodrigues (permaneceu até o n.236) e Santa Rosa (figurou até o n.149), aos quais se juntaram Jacques Bertrand (n.50 a 236), Sotero Cosme (n.111 a 236) e Álvarus (n.127 a 236). A partir do v.6, n.236, p.2, 31/01/1942, quando a distinção desapareceu, alguns artistas do lápis figuraram como redatores, caso de Armando Pacheco e Ruben Gill. 
ges de Augusto Rodrigues e não faltaram séries, como as quarenta e nove caricaturas de Álvarus, consagradas a figuras de proa do mundo literário e cultural, impressas na segunda página. Armando Pacheco e Paez Torres, entre os vários outros artistas, produziram especialmente para Dom Casmurro. Esse conjunto diversificado, além de conferir leveza ao periódico, ilustrava, informava e dava concretude às figuras do mundo da cultura, fossem contemporâneos ou de outros tempos.

Em relação aos demais, ${ }^{20}$ encarregados da parte textual, a questão é bem mais complexa, tendo em vista que aqui as mudanças processavamse com rapidez, o que torna difícil - e mesmo enfadonho - dar conta de cada alteração ao longo de mais de quatrocentos exemplares. No primeiro número, o grupo era composto por Aníbal Machado, Artur Torres Filho, Bandeira Duarte, Carlos Gonçalves, Celestino Silveira, Edith Magarinos Torres, Manoel Bandeira, Mozart Lago e Teófilo de Barros, acrescido no subsequente por Tavares Bastos e Vanderlino Nunes. Deste núcleo inicial, cabe destacar Aníbal Machado e Edith Torres, que acompanharam Brício ao longo de toda a existência da publicação, e Bandeira Duarte, nome frequente entre os redatores, mas cuja presença não foi ininterrupta, enquanto os demais acabaram por se afastar do jornal.

Omer de Mont'Alegre e Joel Silveira, por seu turno, migraram do rol de redatores para a secretaria da redação, trajetória diversa da cumprida por Danilo Bastos, Oliveira e Franklin e Clóvis Gusmão, colaboradores alçados diretamente ao posto. Dentre os que integraram a redação estiveram Alcântara Nogueira, Almeida Fischer, Dorival Cayme, Durval de Azevedo, Fernando Marinho, Franklin de Oliveira, Henrique Maron, Henrique Pongetti, Jaime Adour da Câmara, Josué Montello, Nelson Vainer, Océlio de Medeiros, Osório Nunes e Wilson A. Louzada, portanto um conjunto bastante eclético.

Por ocasião do quarto aniversário, Brício fez um balanço da trajetória de Dom Casmurro e referiu-se aos que estavam ao seu lado em 1937:

Daquela salinha acanhada e estreita no Edifício Odeon ao andar do Edifício Fontes, ${ }^{21}$ onde hoje nos achamos, há uma história linda a contar um dia, desde a animação dos fundadores, a incerteza que nos agoniava envolta na esperança de que o publico nos compreendesse, a alegria da aparição do primeiro número, até a estabilidade de hoje, cercada de consideração e prestígio (...). Éramos poucos no primeiro número, mas dispostos a vencer. Os que faziam parte da redação eram: Álvaro Moreyra: (...) que ainda está aqui com seu bom sorriso animador.

Manuel Bandeira: era o nosso crítico. Foi embora um dia, seis meses depois, por falta de saúde e de tempo. Quando ficou bom quis brigar com a gente. Não adiantou porque a gente gosta dele.

20 A partir do v.7, n.379, p.2, 25/11/1944, os redatores foram denominados de colaboradores.

21 Os endereços foram: Rua do Passeio, 2, Edifício Odeon, $11^{\circ}$ andar, sala 1107 (n.1 a 111); Rua 13 de Maio, n.48, sobrado (n.112 a 127); Rua Evaristo da Veiga, 16, $1^{\circ}$ andar (n.128 a 187) e, finalmente, Praça Marechal Floriano, 55, $2^{\circ}$ andar, Edifício Fontes (n.186 a 452). 
Aníbal Machado: fazia a crítica de arte. Nunca deixou de fazer parte aqui da redação, embora o seu tempo seja escasso.

Celestino Silveira: era o cronista de cinema. Durou um ano. Saiu porque foi fazer o Cine Rádio Jornal, que também venceu.

Tavares Bastos: fazia de tudo. Foi para a França e lá ficou.

Bandeira Duarte: veio fazer a seção Aconteceu nessa semana, criada por Álvaro Moreyra. Um dia O Globo o levou.

Teófilo de Barros: fazia rádio. Durou um ano e foi dirigir a Rádio Tupi, onde tem colhido os louros do seu belo talento.

Mozart Lago: era o da política. Fez crônicas admiráveis. Tornou-se tabelião. Faltou-lhe o tempo.

Edith Magarinos Torres: até hoje continua conosco a movimentar a página feminina, com aquele seu ar de bondade e aquela imensa cultura de poliglota. Augusto Rodrigues: começou aqui sua bela carreira de caricaturista. Um dia A Noite tomou conta dele.

E no meio a figura animadora de Artur Eugenio Magarinos Torres, o primeiro companheiro que tombou, o grande amigo e animador de Dom Casmurro (...).2. Muito tempo depois entraram os outros. Eram moços, extremamente jovens, que vinham de suas províncias à procura de nome. Omer Mont'Alegre, Joel Silveira, Danilo Bastos, Wilson Louzada. Ganharam nome. Tinham talento. À medida que os seus valores iam se impondo, a vida ia levando também com eles, para outras paragens mais rendosas. Foram-se também. ${ }^{23}$

As atribuições de alguns redatores, mencionadas por Brício, remetem para o projeto gráfico da publicação, que conheceu dois momentos bem distintos. No primeiro, do lançamento até maio de 1942 (n.1 a 251), Dom Casmurro apresentava-se com doze páginas, exceção feita aos números especiais de maio (aniversário) e Natal (dezembro), quando contava com vários cadernos e ultrapassava esse montante. ${ }^{24}$ Cada página era encimada por rubrica própria e, não raro, abrigava seções, algumas efêmeras e outras com significativa perenidade. É certo que ao longo desses cinco anos houve deslocamento, mudanças, supressões e introdução de novos títulos, mas havia esforço para ordenar o conteúdo, o que se constituía numa espécie de guia para o leitor, que acabava por se familiarizar com uma dada organização (ver Figuras 5 e 6).

Os redatores respondiam, como se depreende das observações de Brício de Abreu, por páginas inteiras e/ou seções específicas. Assim, enquanto a inicial pode ser considerada um espaço editorial, tomada quase integralmente por textos do proprietário e de quem exercia o cargo de chefe

22 Trata-se do pai de Edith Magarinos. Brício sempre se referiu a ele com gratidão e deixou subtendido, em mais de uma oportunidade, que contou com sua ajuda quando o jornal conheceu dificuldades financeiras.

23 ABREU, Brício. A Semana. Dom Casmurro, Rio de Janeiro, v.5, n.199-200, p.1, 17/05/1941. A crônica de Brício, inicialmente denominada "Nós", trouxe, entre fins de 1940 e o início do ano seguinte, o subtítulo "A Semana", que acabou por se firmar, definitivamente, a partir do v.4, n.187, p.1, 08/02/1941.

24 As edições especiais tinham, por vezes, temática única, como as dos Natais de 1937, dedicada à França, 1938. Paris e Rio de Janeiro, 1944, Barão do Rio Branco, 1945, Molière, 1946, Shakespeare, e as dos aniversários de 1939, Machado de Assis, 1940, São Paulo, 1942, Bahia. Em 1944, o Centenário de nascimento de Paul Verlaine mereceu número especial, em agosto. 
da redação, a que se intitulava "Crítica" (que poderia ser a quinta ou a sexta página), estratégica para um jornal literário, foi ocupada, em diferentes momentos, por Manoel Bandeira, Josué Montello, Océlio de Medeiros, Wilson Louzada, Pinheiro de Lemos e Denise de Lima e Silva, a quem coube dar conta, por certo tempo, das publicações saídas na França, o que era feito no idioma original. "Livros", "Montras e Prelos", "Revista dos Livros", "Livro Nacional", "Livro Estrangeiro", "Bibliografia", "Jornais e Revistas", estão entre as seções que a compuseram. Em Dom Casmurro, era praxe que os lançamentos recebessem mais de uma apreciação, sobretudo quando se tratava de nomes consagrados, e tampouco foi incomum o debate em torno de avaliações contrastantes.

O acompanhamento sistemático das recensões e das notícias sobre o aparecimento de jornais e revistas, bastante frequente, oferece oportunidade para o pesquisador esquadrinhar o mundo dos impressos das décadas de 1930 e 1940. Tampouco são destituídos de importância os abundantes anúncios de livrarias e editores, que divulgavam seus catálogos e as obras recém-lançadas. Os estudiosos da história do livro e da leitura têm apontado a importância desse momento para a consolidação do setor editorial brasileiro, que se fortaleceu a ponto de lançar um empreendimento coletivo, - Anuário Brasileiro de Literatura, amplamente divulgado no semanário.

Ao lado das novidades literárias havia, pelo menos de saída, a intenção de também dar conta do que passava no cinema, rádio, concertos, teatros e esportes, tópicos que deveriam compor o campo de interesses de um leitor disposto a adquirir Dom Casmurro. No projeto original, alterado já em fins 1937, contava-se com "Câmara" (página sete), "Espetáculos" (página dez), consagrada ao palco e que trazia a seção "Microfone", e "Esportes" (página onze), todas fartamente ilustradas e com várias propagandas relacionadas às temáticas tratadas. Contudo, esse compromisso com a atualidade esportiva e cultural, importante para uma publicação com esse perfil, não se manteve e tais informações que, no início, dispunham de três páginas, acabaram concentradas numa única página (a dez ou a onze, segundo o momento), com as notícias esportivas merecendo atenção cada vez menor, até deixarem de ser contempladas.

O mesmo destino teve "O Rio em 7 dias", rubrica que, por pouco mais de um ano, identificou a página seis e na qual se localizava, de início, a seção "Aconteceu nessa semana", além de "No Fórum", que tratava de questões jurídicas, Sabendo pode contar, notas curtas e curiosas, e ensaios sobre economia e medicina, o que bem evidencia o seu ecletismo. Não raro, o conteúdo da página ficava longe de fazer jus ao título, o que talvez explique o abandono do mesmo em prol de outros ("De Arte", "Todas as Idéias", "Outras Máscaras", "Em Geral"), que alteravam o sentido original e não exigiam, necessariamente, compromissos com a notícia e o evento recém-ocorrido, apurado pelo repórter. A observação não cabe apenas para 
a página, mas também para "Aconteceu nessa semana", seção publicada ao longo de centenas de edições e que contou com vários titulares, cujo conteúdo surpreende o leitor contemporâneo pela distância entre o que se anuncia e o que se lê, pois nela os acontecimentos são largamente superados pelas notas de humor e faits divers. ${ }^{25}$

Contudo, tais observações não significam que os idealizadores não tivessem em mira questões contemporâneas. De fato, parece plausível supor que a segunda página foi concebida para tal fim, como indica a reprodução de artigos de figuras de proa do cenário internacional, caso de Winston Churchill, e a presença de Azevedo Amaral, Evaristo de Morais, Murilo Mendes e a coluna de Mozart Lago, por sinal de vida breve. As contribuições de Murilo, datadas de 1937, distinguiam-se pelos ataques aos integralistas, o que valeu a Brício vários dissabores por ocasião do golpe do Estado Novo - encarceramento, proibição de circulação do jornal, uma enxurrada de cartas anônimas contra a publicação - atribuídos à campanha do Correio da Manha e de folhas integralistas, que qualificavam Dom Casmurro de jornal francês e comunista, o que afastou os anunciantes e ameaçou a existência da publicação, como ele fazia questão de frisar nos balanços de aniversário. ${ }^{26} \mathrm{~A}$ partir do segundo ano de circulação (maio de 1938), esta página, a única a não ter título próprio, ganhou rubrica fixa ("O ano corrente", "A semana" e, finalmente, "Tempo"), o que corrobora a interpretação aventada.

É certo que acontecimentos de grande significado - como o início da Segunda Guerra, a queda da França, o ataque a Pearl Harbour, a Conferência de Chanceleres no Rio em 1942, a entrada do Brasil no conflito, para ficar em alguns poucos exemplos - acabavam recebendo atenção, seja na coluna de Brício, em seções ou ensaios, por mais que se insistisse em definir a folha como de divulgação cultural - afinal, cultura e política não podem ser contidas em compartimentos rígidos. O fato é que em Dom Casmurro grande parte da matéria publicada não se subordinava aos acontecimentos do

25 Vejam-se os seguintes excertos: SILVEIRA, Joel. Aconteceu nessa semana. Dom Casmurro, Rio de Janeiro, v.3, n.40, p.4, 24/02/1940, "Segunda Feira, 21. Mr. Eden deixou o gabinete inglês. Magnólia chegou em casa afobadíssima. Gritando que ia se jogar no mar, que ia beber veneno, que a vida não valia mesmo nada. A mãe veio com as mãos nas ancas perguntando: Que foi menina? Ela então não soube responder... e a graça está nisto mesmo...." e CARIOCA, Juca. Aconteceu nessa semana. Dom Casmurro, Rio de Janeiro, v.7, n.286, p.2, 23/01/1943: "Sábado 16. Abelardo Romero escreveu o seguinte bilhete para o seu amigo e companheiro de imprensa, Jose Lira: 'Peço o favor de me mandar 20 cruzeiros para ir jantar. P.S: Refleti e pelo que me mande 25'. O José Lira respondeu: 'Atencioso Romero: Envio-te os 20 cruzeiros que me pedistes. P. S. Refleti e vou jantar com eles'. Domingo 17. A RAF, representada por poderosa força de bombardeiros pesados atacou Berlim, novamente, arrojando grande quantidade de bombas sobre a capital alemã".

26 Ver: ABREU, Brício. 52 Semanas. Aniversário. Dom Casmurro, Rio de Janeiro, v.2, n.51, p.1, 21/05/1938; ABREU, Brício. Nós. Dom Casmurro, Rio de Janeiro, v.2, n.52, p.1, 26/05/1938; ABREU, Brício. Nós. $2^{\circ}$ aniversário. Dom Casmurro, Rio de Janeiro, v.3, n.101-102, p.1-2, 20/05/1939; ABREU, Brício. Nós. Bilan de dois anos. Dom Casmurro, Rio de Janeiro, v.3, n.103, p.2, 07/05/1939; ABREU, Brício. Nós. Bilan de dois anos (cont.). Dom Casmurro, Rio de Janeiro, v.3, n.104, p.1, 03/06/1939; ABREU, Brício. Nós. Fim de Bilan. Dom Casmurro, Rio de Janeiro, v.3, n.105, p.1, 10/06/1939; Idem. Terceiro aniversário. Dom Casmurro, Rio de Janeiro, v.4, n.149, p.1, 18/05/1940 e, por fim, ABREU, Brício. A Semana. Dom Casmurro, Rio de Janeiro, v.5, n.201, p.1, 24/05/1941. 
cotidiano e o compromisso de informar e noticiar ocupava lugar secundário. Em contrapartida, avultavam os ensaios densos sobre escritores, filósofos, cientistas, artistas, teorias sociológicas, com abundante colaboração internacional e não raro compondo longas séries. É significativo que a primeira rubrica a substituir "Câmara", página antes consagrada ao cinema, tenha sido "Grandes Estudos".

A criação literária também tinha lugar em Dom Casmurro, com muitas páginas dedicadas à poesia e à publicação de livros em capítulos, no estilo folhetim. Até maio de 1941, a terceira página intitulou-se "Romance" e nela o público acompanhou Mayerling, de Claude Anet, Madame Tallien, de autoria de sua neta, Princesa de Chimay, A Gata, de Colette, ao lado de Dom Casmurro, de Machado de Assis, Memórias de um sargento de milícias, de Manoel Antonio de Almeida, além de várias páginas literárias que não eram, de fato, romances. E não foi somente aí que a literatura encontrou espaço: notícias publicadas na página "Esportes" dividiam espaço com livros do gênero policial, como O punhal de cristal, de Rodolfo Bringer. Contrariamente ao jornal de notícias, descartado ao final do dia, Dom Casmurro era insistentemente apresentado como "um jornal que se lê e se guarda. É o único no seu gênero com repercussão em todo o Brasil".

Rubricas como "O tempo que vai passando", "Lá no tempo", "Foi assim" indicam um compromisso com o passado, do que não se deve concluir que o conteúdo tenha sido sempre fiel ao título da página, pois ao lado de textos dedicados a personagens de antanho também se alinhavam excertos de literatura contemporânea, críticas e resenhas.

Algumas páginas mantiveram-se inalteradas, caso da quarta, "Máscaras do Mundo", que reunia rol variado de textos e se constituía num espaço de celebração de escritores, cientistas, pintores e filósofos. Nos anos iniciais, observa-se grande esforço para ilustrá-la com fotos, desenhos e charges, aí incluídos os que escreviam ou dirigiam Dom Casmurro. O mesmo podese dizer da nona página, "Para você", sempre a cargo de Edith Magarinos, com sua coluna "De leve", que fazia às vezes de editorial. Neste recanto feminino, informava-se a respeito das tendências da moda, sobretudo a parisiense, e ofertava-se abundante material literário (poesias, excertos em prosa, frases de autores/autoras famosas), além de informações sobre a vida e a obra de artistas do rádio e do cinema. Personagens do mundo das ciências, letras, pintura, escultura mesclavam-se às receitas, conselhos e beleza, não faltando mesmo, por certo tempo, respostas às perguntas dirigidas ao jornal que, como seria de se esperar em publicação desta natureza, não reproduzia a questão e tampouco identificava a leitora.

Perenidade também foi marca distintiva das "Grandes Reportagens Exclusivas", que fechavam a publicação e que não guardavam, necessariamente, vinculação com o aqui e agora, como o termo reportagem poderia sugerir. Comportavam, por exemplo, testemunhos sobre Primeira Guerra 
Mundial, relatos de viagens, biografias, como a série sobre magnatas, análises de livros, filmes e obras de arte plásticas, curiosidades do mundo científico, entrevistas com personalidades nacionais e estrangeiras, enfim uma miríade de temáticas que, no mais das vezes, ocupavam várias edições.

Tal estruturação do conteúdo, aqui descrita de forma sumária e sem a preocupação de fornecer panorama exaustivo de todas as seções presentes nas diferentes páginas de Dom Casmurro desde 1937, alterou-se de forma significativa em 30 de maio de 1942 (n.252), quando as páginas deixaram de conter rubricas. O fato coincidiu com a diminuição do número das mesmas, de doze para oito, justificada, em termos de dramáticos, por Brício de Abreu, que evocou a falta crônica de papel, ocasionada pela guerra em curso. A partir de seis de outubro de 1945 (n.421), a periodicidade tornou-se quinzenal, a despeito de o subtítulo "grande hebdomadário brasileiro" não haver desaparecido do cabeçalho nem mesmo entre maio de dezembro de 1946, quando as edições do "semanário" espaçaram-se ainda mais.

Apesar da redução de um terço e da supressão dos títulos das páginas, observa-se a preocupação de preservar certos espaços. Edith Magarinos instalou-se na página quatro e teve sua contribuição resumida à coluna "De leve", enquanto Madô (pseudônimo não identificado) assinava "A moda". A edição continuou a encerrar-se com "Grandes Reportagens Exclusivas", enquanto a penúltima página concentrou as informações (e propagandas) sobre cinema, rádio, música, espetáculos teatrais em cartaz que, não raro, apresentavam-se estruturada em seções ("De rádio", "De música", "Saibam que", agora contendo sinopse de filmes em cartaz). A crítica continuou presente em "Vida Literária" e "Revista de Livros", enquanto fatos curiosos que envolviam escritores e editores compunham a seção "Porta de Livraria". Sebastião Fonseca escrevia "Barbas de Molho", que se constituía numa espécie de crônica em versos; "Aforismos e Des... aforismos" era assinada por F. R., "Coisas do Rio Antigo" esteve a cargo de Roque Taborda. Tais seções estão entre as mais duradouras, mas não foram as únicas a ocuparam as colunas do jornal e nem todas foram publicadas simultaneamente. Excetuando-se as seções, as enquetes - a exemplo da encetada por Osório Nunes, "O modernismo morreu?", respondida, ao longo de vários números, por escritores, artistas e músicos - e as séries - como a de Ruben Gill, "O século boêmio", que entre outubro de 1942 e janeiro de 1945 analisou, em setenta e duas contribuições, caricaturistas, periódicos e homens da imprensa desde o final do século XIX - o restante do conteúdo não tinha qualquer estruturação (ver Figura 7 e 8).

Vale ainda notar que, com a segunda saída de Álvaro Moreyra da chefia de redação, o posto ficou vago e a coluna de Brício, intitulada "A Semana", passou a dividir espaço com outros temas. Entre 1942 e o início de 1944, as considerações do proprietário migraram para o interior do periódico (página três e, depois, a dois), o que alterou o escopo inicial da primeira 
página, uma vez que o espaço editorial foi ocupado por assuntos variados, que incluíam desde a passagem de efemérides, a exemplo do tricentenário da morte Galileu; textos de autores do momento, caso de excerto, em francês, de livro de Saint-Exupéry, acompanhado de autógrafo para os leitores brasileiros; impressões dos que vivenciavam os acontecimentos da guerra em curso; notícias de regiões distantes e até mesmo o que foi denominado de "reportagens retrospectivas", como a de Gonzaga Duque sobre o carnaval carioca. Entre 1944 e 1946, Brício voltou a ocupar a página de abertura, mas de forma intermitente, pois nem todas as edições de Dom Casmurro traziam a palavra do diretor. Nessa página de abertura sempre havia preocupação de incluir material iconográfico o que, entretanto, não se observa para o restante da edição, sobretudo quando contraposta à fase anterior (ver Figuras 9 e 10).

\section{Panorama da trajetória}

As mudanças observadas a partir do quinto ano de publicação de Dom Casmurro, iniciado em maio de 1942, não se limitaram à alteração do projeto gráfico, redução do número de páginas e enxugamento da redação. Há indícios de perda de vitalidade, perceptível, por exemplo, no retraimento das propostas do jornal. A comemoração do primeiro aniversário, em maio de 1938, mereceu edição de vinte e quatro páginas, capa com fotografia de redatores e colaboradores destacados. Nesse momento, o jornal contava com vinte e seis mil leitores e perto de quatro mil assinantes, de acordo com os responsáveis. Talvez embalados pelo sucesso obtido, a despeito das dificuldades relatadas por Brício, decidiram, em outubro do citado ano, expandir as ações do semanário, o que foi comunicado aos leitores nos seguintes termos: "O plano cultural de Dom Casmurro não quer se limitar apenas à expansão do jornal. Quer levar mais à frente os seus propósitos com a publicação de livro, com a realização e conferências, de concertos, de exposições, de exibições cinematográficas". ${ }^{27}$

Assim, anunciavam-se conferências culturais e debates a cargo de Jayme Adour da Câmara, Almir de Andrade, Álvaro Moreyra, Marques Rebello, Mário e Oswald de Andrade, sendo que apenas os três primeiros levaram a termo a empreitada, amplamente divulgada no jornal, ao que se deve somar a primeira (e única) sessão de cinema cultural, com filmes de Chaplin, apresentados e discutidos por Roquete Pinto e Roberto Assunção, realizada em dezembro. $O$ fim desse tipo de atividade coincidiu com o lançamento do Grande Concurso de Contos Inéditos de Escritores Brasileiros, que se estendeu até julho do ano seguinte, quando a comissão julgadora,

27 Conferências Culturais de Dom Casmurro. Dom Casmurro, Rio de Janeiro, v.2, n.72, p.2, 15/10/1938. 
composta por Almir de Andrade, Álvaro Moreyra, André Carrazoni, Graciliano Ramos, Joracy Camargo e Oduvaldo Vianna proclamou os dez vencedores dentre os quase setecentos concorrentes, ${ }^{28}$ que tiveram suas produções semanalmente estampadas na página Romance. Pouco depois, Jorge Amado, então na chefia da redação, dava a conhecer novo concurso, agora de romances, em parceria com a Editora Vecchi, a quem caberia imprimir os dois textos vencedores, que ainda receberiam prêmios em dinheiro.

O segundo aniversário, em maio de 1939, foi celebrado com banquete no Cassino Atlântico e contou com ampla lista de comensais, que incluía dirigentes de jornais, escritores e políticos. Os ausentes acharam necessário apresentar justificativas, acompanhadas das protocolares congratulações, divulgadas nas páginas do jornal, caso, por exemplo, de Mário de Andrade e Carlos Drummond de Andrade. As notas de órgãos da imprensa e de figuras de proa, entre as quais estava o Ministro Gustavo Capanema, também foram reproduzidas. A edição comemorativa, com mais de trinta páginas, foi dedicada a Machado de Assis e, conforme se anunciou na capa, tratava-se de contribuição oficial do Estado do Rio Grande do Sul ao centenário de nascimento do escritor. O afã celebrativo marcou 1939, tanto que o jornal ofereceu novo banquete, em 14 de dezembro, agora no Cassino da Urca, para homenagear os ficcionistas que publicaram no decorrer do ano. Pretendia-se reunir não apenas "todos os grandes nomes da nossa literatura, arte e jornalismo", mas também "o mundo oficial e o corpo diplomáticos, especialmente convidados". Talvez para que os leitores pudessem dimensionar o evento, publicava-se a lista dos escritores homenageados, organizada por Estado da Federação, e de convidados, emoldurada pela foto dos primeiros. ${ }^{29}$

Neste ano foram publicados quatro números temáticos, dedicados ao Rio Grande do Sul (n.89), Centenário de Tobias Barreto (n.106), Sesquicentenário da Revolução Francesa (n.110) e Cinquentenário da Proclamação da República (n.124 e n.125). A proximidade com o Rio Grande chama a atenção, ainda mais porque foi justamente no número noventa e um, portanto após a edição dedicada ao Estado, que não economizou elogios aos dirigentes locais, que foi inaugurada a sucursal de Porto Alegre, dirigida por Manoelito de Ornellas, diretor da Biblioteca Pública, além das agências de Fortaleza e Belo Horizonte, logo seguida pela de São Paulo e por várias outras, expansão que atingiu o auge em abril de 1942 (n.245), oportunidade em que foram listadas trinta e quatro sucursais.

O ano de 1940 abriu-se com campanha em prol do aumento do número de assinantes, proposta nos seguintes termos:

28 O nosso grande concurso de contos. Dom Casmurro, Rio de Janeiro, v.3, n.109, p.3, 08/07/1939.

29 O grande banquete de confraternização intelectual. Dom Casmurro, Rio de Janeiro, v.3, n.128, p.3, 09/12/1939. 
Colabore na grande obra de difusão cultural que Dom Casmurro está realizando - faça parte da campanha das 10.000 assinaturas, procurando que seus amigos e conhecidos tomem uma assinatura anual de Dom Casmurro (...) que possui atualmente 5327 assinantes e em fins de fins de 1940 terá 10.000, se você colaborar com ele. A todos os amigos que nos enviarem cinco assinantes reservamos uma surpresa interessantíssima. ${ }^{30}$

Os Estados de São Paulo, na edição de aniversário, e de Minas Gerais, em número temático de setembro, receberam atenção, ainda que desta vez a ênfase tenha recaído mais em aspectos históricos, literários e culturais do que em personalidades que ocupavam altos postos, como ocorreu em relação ao Rio Grande. O resultado do concurso de romances, que premiou Dalcídio Jurandir e Clóvis Ramalhete, agitou as páginas do jornal a partir de julho, com detalhes sobre os laureados, análises das obras, entrevistas e repetidas notas sobre o lançamento dos livros pela Editora Vecchi. No início de outubro, surgiram os primeiros anúncios da Coleção Dom Casmurro, em parceria com a Alba Editora e sob a direção de Brício e Álvaro, que pela segunda vez ocupava a chefia de redação. ${ }^{31}$ Poucos números depois, a literatura infantil era alvo de nova iniciativa do semanário e da Alba, agora para premiar obra de História do Brasil, destinada ao publico infantil.

No que tange à coleção, as cartas que Ramalho Ortigão recebeu de Eça de Queiroz, Camilo, Guerra Junqueiro, Fialho e outros escritores, publicadas ao longo de 1938 em primeira mão no periódico e que integrava os esforços do semanário no sentido de estreitar relações com Portugal, ${ }^{32}$ constituíram-se no primeiro volume, impresso em novembro de 1940 e acompanhado de paratextos dos diretores. Pais espoliado, de Geraldo Rocha, veio à luz logo em seguida, enquanto Mayerling e Madame Tallien, romances já publicados no semanário sob a forma de folhetim, também foram prometidos, ainda que somente o primeiro tenha sido efetivamente saído, a julgar pelos dados constantes no periódico. ${ }^{33}$

Aliás, a publicação da obra de Claude Anet, no início do ano seguinte, coincidiu com a exibição da versão para o cinema, o que motivou a organi-

30 Dom Casmurro, Rio de Janeiro, v.3, n.135, p.1, 27/01/1940. Na última edição deste ano, datada de 28 dez 1940, reproduziu-se, na última página, nota fiscal de 1938, atentando que então se imprimiam 18 mil exemplares, contra 25 mil do ano corrente, ao que se acrescentava: "Eis a tiragem semanal de Dom Casmurro, que é o jornal para a sua publicidade".

31 Eis a integra da notícia: "Dom Casmurro acaba de firmar um contrato com a Alba Editora do Rio, para a criação de uma verdadeira biblioteca, a coleção Dom Casmurro sob a direção de Álvaro Moreyra e Brício de Abreu, onde serão apresentados os mais notáveis livros nacionais e estrangeiros. Reserve desde já no seu livreiro os dois primeiros volumes desta magnífica coleção ilustrada que aparecerão em princípio de dezembro". Dom Casmurro, Rio de Janeiro, v.4, n.169, p.4, 05/10/1940.

32 Esta foi outra preocupação constante, expressa nos muitos estudos sobre autores portugueses, atenção às revistas daquele país e presença de escritores e ensaístas contemporâneos entre os colaboradores. Em agosto de 1939, anunciou-se a seção "Crítica de Livros Portugueses", a cargo de Antonio Amorim.

33 No primeiro volume, dedicado às cartas recebidas por Ortigão, listam-se os títulos subsequentes: Mayerling, Claude Anet, A Gata, Colette, Madame Tallien, Princesa de Chimay, Turgueniev, André Maurois, A vida de cabeça baixa, Álvaro Moreyra, e a Coleção Infantil com O boi Aruá, Luis Jardim, premiado pelo Ministério da Educação. Note-se que não há menção ao livro de Geraldo Rocha. 
zação de certame, no qual os leitores eram convidados a comparar o texto romanesco com o filme, do que resultaram mais de duzentas respostas, cabendo a Brício, Álvaro e Edith escolher e premiar o melhor texto. ${ }^{34}$ Com toda essa atividade, não admira que os responsáveis tenham ocupado mais de uma página com telegramas e reprodução de notas da imprensa relativas à passagem do quarto aniversário.

Ao mesmo tempo em que o projeto da Coleção tomava corpo, e o concurso de literatura infantil seguia com inscrições abertas, os leitores eram constantemente alertados, tal como ocorreu em 1940, sobre a proximidade da chegada às livrarias dos romances de Dalcídio Jurandir, Chove nos campos de Cachoeira, e Clóvis Ramalhete, Ciranda, o que se concretizou em meados de 1941. Imediatamente instituiu-se outra contenda para premiar as melhores críticas. O ritmo das propostas acelerava-se e, nesse mesmo momento, em parceria com Procópio Ferreira e Dulcina e Odilon, foi aberta outra competição para escolher peças em três atos, a serem encenadas pelas companhias.

Entretanto, várias das proposituras acabaram por não se efetivar, o que parece ter sido o caso do certame dedicado à literatura infantil, cujo encerramento foi sendo postergado até cair no esquecimento, mesmo destino da crítica aos romances premiados. Já o concurso de teatro encerrou-se melancolicamente a três de janeiro de 1942 (n.232), pois, a despeito de contar com perto de sessenta concorrentes, nenhum atendeu às necessidades dos patrocinadores. O único projeto novo, anunciado nessa mesma edição, prometia um caderno extra com peças, a sair na primeira semana de cada mês. Entretanto, até o encerramento de Dom Casmurro em 1946, apenas catorze foram editados, um deles com patrocínio explicito da Caixa Econômica Federal. ${ }^{35}$

Data de 1942 a retração das sucursais que, de mais de uma trintena, resumiram-se às de Porto Alegre, Salvador e São Paulo, situação que perdurou até junho de 1944 (n.356), quando permaneceu apenas a paulista que, segundo se informava, mantinha representantes em todas as capitais do Brasil. Já as comemorações pela passagem do sexto aniversário foram marcadas por edição dedicada à Bahia, com todo o terceiro caderno devotado aos feitos do governo e autoridades, cabendo assinalar que, em março de 1942, o diretor visitou o Estado homenageado a convite do interventor. No retorno, Brício deu início à campanha para a construção de mausoléu para Castro Alves, que se estendeu por muitas edições. Já os habituais cumprimentos por mais um ano de circulação resumiram-se a uma nota de Clóvis Beviláqua.

Em 1943, o diretor assinalou as dificuldades para preparar a edição especial de aniversário, num momento em que a guerra tomava proporções efetivamente mundiais, ainda uma vez evocou os embates dos primeiros tem-

34 O vencedor foi reproduzido em O concurso de Dom Casmurro sobre o livro e o filme Mayerling. Dom Casmurro, Rio de Janeiro, v.5, n.202, p.2, 31/10/1941

35 Trata-se do Caderno 12 e a informação está em Dom Casmurro, Rio de Janeiro, v.8, n.412, p.8, 04/08/1945. 
pos e agradeceu o envio ao exterior, pelo DIP, da edição do Natal de 1942, o que valeu notas de elogio por parte da imprensa norte-americana. ${ }^{36}$ Nos anos subsequentes, a fundação foi assinalada tão somente pelas edições especiais.

\section{Um equilíbrio difícil}

O arrefecimento das atividades e as mudanças na materialidade fizeramse acompanhar de outras alterações. Não é tarefa simples dar conta dos colaboradores de uma publicação com o perfil de Dom Casmurro. Porém, o folhear atento dos exemplares evidencia não apenas o retraimento das contribuições internacionais, compreensível em vista da guerra em curso, mas também a progressiva escassez de nomes que desfrutavam de maior prestígio, como Mário de Andrade, Graciliano Ramos, Rubem Braga, Érico Veríssimo, Jorge de Lima, Marques Rabelo, Jorge Amado, Santa Rosa, José Lins do Rego, Roger Bastide. Estes, a exemplo dos jovens revelados pelo semanário, deixaram de frequentar suas páginas. Em compensação, o ano de 1942 foi marcado pela proximidade com a sucursal de São Paulo, que remetia notícias sobre os acontecimentos culturais do Estado e contava com matérias do jornalista Nelson Vainer, então seu diretor e que chegou a integrar a redação. A inauguração da seção paulista do Departamento de Imprensa e Propaganda e as atividades promovidas pelo órgão encontraram espaço nas páginas de Dom Casmurro. O mesmo se pode afirmar em relação a Getúlio Vargas, cujas viagens e mesmo pronunciamentos, como o que marcou o sete de setembro do citado ano, foi integralmente reproduzido.

A questão das relações do semanário com os órgãos de controle da informação ainda demanda investigações mais sistemáticas. Contudo, a julgar pelo conteúdo, é possível perceber que a tensão dos meses que se seguiram ao golpe do Estado Novo, repetidamente evocada do Brício, foi progressivamente cedendo lugar a uma aproximação cada vez mais amistosa. Desde o lançamento, Brício levantou duas bandeiras: a da necessidade de renovar a cena teatral e a da elaboração de leis que protegessem as atividades intelectuais e que regulassem questões como pagamento de direitos autorais. No que tange ao teatro, a decisão do Ministério da Educação de apoiar a Companhia de Álvaro e Eugenia Moreyra foi amplamente aplaudida nas páginas do jornal. Entretanto, tal postura constituiu-se numa exceção, pois as medidas do Serviço Nacional do Teatro, subordinado a Capanema, foram alvos de ataques sistemáticos por parte de Brício, que tomava o cuidado de preservar o ministro e culpar o diretor do órgão pela má condução da política para o setor.

36 ABREU, Brício. Sétimo aniversário. Dom Casmurro, Rio de Janeiro, v.7, n.300-301, p.12, 15/05/1943. De fato, tratava-se do sexto aniversário. Cumpre esclarecer que, até 1941, a numeração do volume alterava-se em meados de maio, quando da passagem do aniversário da publicação, lançada em 13 de maio de 1937. A partir de 1942, a mudança passou a ocorrer já no exemplar de janeiro, o que explica a referência de Brício. 
Na outra frente, Brício insistia na urgência de se amparar o intelectual, a exemplo do que então ocorria com várias outras categorias de trabalhadores. Apelava para autoridades, como o Ministro do Trabalho e o Presidente da República, criticava a atuação de instituições como o PEN Clube, organizado no Brasil em 1936 e cuja primeira diretoria foi instalada em 1937, tentou organizar a Sociedade Brasileira de Gentes de Letras, lançada no banquete de aniversário de 1939 e que não prosperou. A Casa dos Artistas, que foi dirigida por Eugenia Moreyra, exemplificava as penúrias enfrentadas pelos outrora profissionais do teatro e da música. Tais iniciativas, que exigiam diálogo com o poder, não comprometiam, segundo acreditava, o rigoroso afastamento das questões políticas, uma vez que se tratava de defender causas específicas e afeitas ao universo da cultura. A mesma lógica era aplicada aos comentários elogiosos a Lourival Fontes, até agosto de 1942 diretor dos sucessivos departamentos encarregados da propaganda, de quem se dizia próximo e que era sempre referido na sua condição de intelectual.

Ainda que de forma impressionista, é possível perceber uma inflexão importante a partir de janeiro de 1942, quando o Brasil oficialmente decidiu-se pelos Aliados. Antes desta data, a guerra foi um tema pouco presente, o que também vale para a queda da França, fato que não deixa de ser surpreendente, tendo em vista a proximidade de Brício com o hexágono. Bem diversa é a situação posterior, quando se multiplicaram as referências ao conflito e seus personagens (primeiras páginas dedicadas à questão, charges e caricaturas de Hitler, situação na Alemanha, menções aos Estados Unidos e ao panamericanismo, antes bissextas) e os artigos semanais sobre a França. É sintomático que De braços abertos para a França, reunião de textos publicados em Dom Casmurro entre maio de 1937 e agosto de 1943 sobre La douce France, para retomar a expressão tantas vezes utilizada por Brício, contenha apenas um registro para o período junho de 1940 a junho de 1942. Essas indicações, ainda que breves, estão em consonância com as análises historiográficas que assinalam mudanças no clima imperante no país depois do rompimento com o Eixo. No caso de Dom Casmurro, ao lado das alterações no conteúdo, há indícios que apontam para significativa aproximação com o poder. ${ }^{37}$

\section{Conclusão}

As breves considerações apresentadas evidenciam as potencialidades que o estudo sistemático de Dom Casmurro pode trazer tanto para a

37 COSTA, Cristina. Teatro e censura: Vargas e Salazar. São Paulo: Edusp, 2010, p.106, ao referir-se ao acordo firmado entre Antonio Ferro e Lourival Fontes em abril de 1942, que originou a seção brasileira do Secretariado de Propaganda Nacional, em Lisboa, informa que "entre uma de suas principais funções estava o que poderíamos chamar de 'assessoria internacional de imprensa' do Estado Novo, com o envio de notícias, artigos e fotos para distribuição à imprensa brasileira, especialmente os jornais Estado de São (sic) Paulo, Dom Casmurro, Aspectos e Voz de Portugal". Vale lembrar que O Estado estava nas mãos do DIP. 
compreensão das questões que atravessavam o mundo cultural e literário quanto para a história da imprensa. Cabe destacar que, especificamente em relação às revistas literárias e culturais que circularam no primeiro governo Vargas, há escassa fortuna crítica e carência de investigações aprofundadas, o que limita a compreensão do papel da imprensa no período. De fato, com honrosas exceções, não se avança muito além da alusão à data de lançamento, direção, lista de colaboradores consagrados e afirmações genéricas quanto à importância da publicação para o mundo letrado.

A historiografia continua a insistir na decantada subserviência dos impressos ao poder, o que, no limite, não justificaria tomá-los como objeto. A averiguação sistemática desses periódicos poderia matizar as afirmações genéricas acerca do grau de controle da informação atingido pelo Estado. Obviamente não se trata de negar o exercício da censura, as arbitrariedades e as tentativas de, via coerção, impor o consenso, o que de fato foi perseguido de forma ardorosa e sistemática. Tampouco é o caso de ignorar a disposição, muitas vezes regada a favores de toda espécie, para a concordância, aspectos já competentemente explorados pela produção acadêmica ${ }^{38} \mathrm{O}$ esforço caminha no sentido de evidenciar possibilidades outras além da colaboração que, afinal, não estava pré-determinada e assegurada pela existência de instituições dedicadas a vigiar, controlar e cercear. Não se pode desprezar o fato de que também havia disposição para contestar, questionar ou burlar, o que exige tomar as publicações literárias e culturais em toda a sua complexidade e assumir que não atuaram de forma unívoca, como indica o exemplo do jornal dirigido por Brício de Abreu, cuja postura face ao poder comportou tensões e variações ao longo de sua existência. Em outras palavras, trata-se de evitar rótulos unidimensionais, tipo pró ou contra o regime, e atentar para a dinâmica dos posicionamentos na travessia de uma conjuntura complexa, marcada pelo acirramento de posições e disputas políticas.

Esquadrinhar as páginas de Dom Casmurro poderá colaborar para relativizar as breves (e duras) linhas que Sodré dedicou ao jornal no seu clássico estudo sobre a imprensa - a "coleção espelha com fidelidade o baixo nível da atividade literária da época" ${ }^{39}$ Já o confronto com outros periódicos contemporâneos, caso da terceira fase da Revista do Brasil (1938-1943), que efetivamente opôs-se à maré dominante, ${ }^{40}$ da Revista Acadêmica (1933-1948) e de Diretrizes (1938-1944) quiçá revele um quadro bem mais matizado e complexo do que o vigente na história da imprensa.

38 CAPELATO, Maria Helena R. Multidões em cena: propaganda política no varguismo e no peronismo. Campinas, SP: Papirus, 1998; GARCIA, Nelson Jahr. Estado Novo: ideologia e propaganda política. São Paulo: Loyola, 1982; LENHARO, Alcir. A sacralização da política. Campinas, SP: Papirus/UNICAMP, 1986; PAULO, Heloisa. Estado Novo e propaganda em Portugal e no Brasil: o SPN/SNI e o DIP. Coimbra: Edições MinervaCoimbra, 1994; SOUZA, José Inácio Melo. A ação e o imaginário de uma ditadura: controle, coerção e propaganda política nos meios de comunicação durante o Estado Novo. São Paulo: Universidade de São Paulo, 1990. (Comunicações, Dissertação de mestrado)

39 SODRÉ, Nelson Werneck. História da imprensa no Brasil. Rio de Janeiro: Civilização Brasileira, 1966, p.444.

40 LUCA, Tania Regina de. Leituras, projetos e (re)vista(s) do Brasil (1916-1944). São Paulo: Editora Unesp, 2011. 

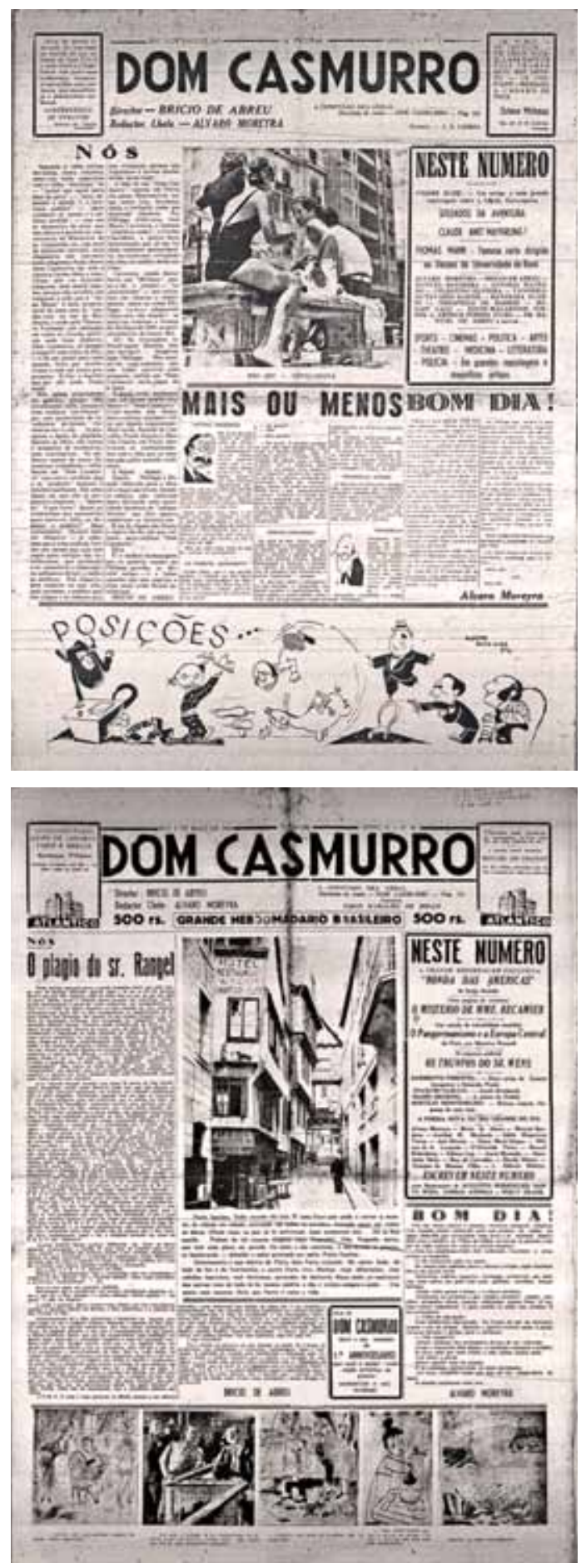

Figuras 1 e 2. Páginas iniciais (maio de 1937 e maio de 1938), com padrão idêntico e nas quais se reservava espaço para anunciar o conteúdo da edição. 

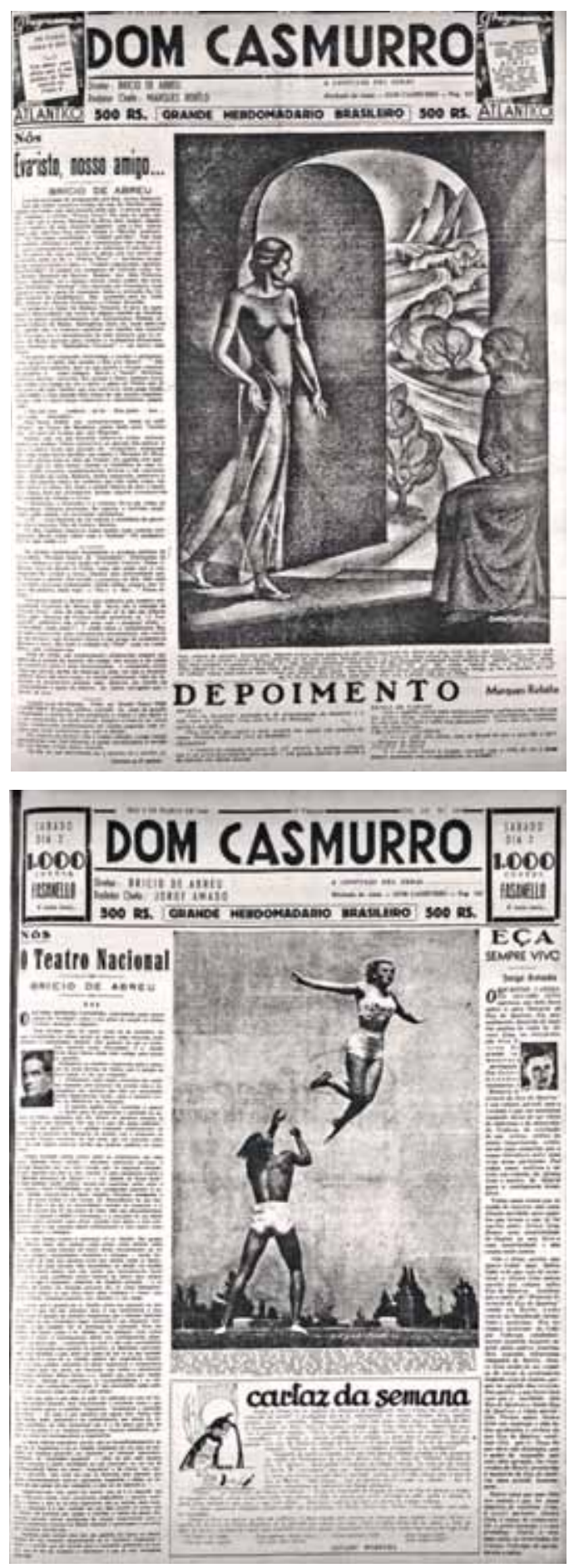

Figuras 3 e 4. Exemplos de capas de 1939 e 1940, compostas com apuro técnico. Ainda que diversas das anteriores, constituíam em espaço editorial. 

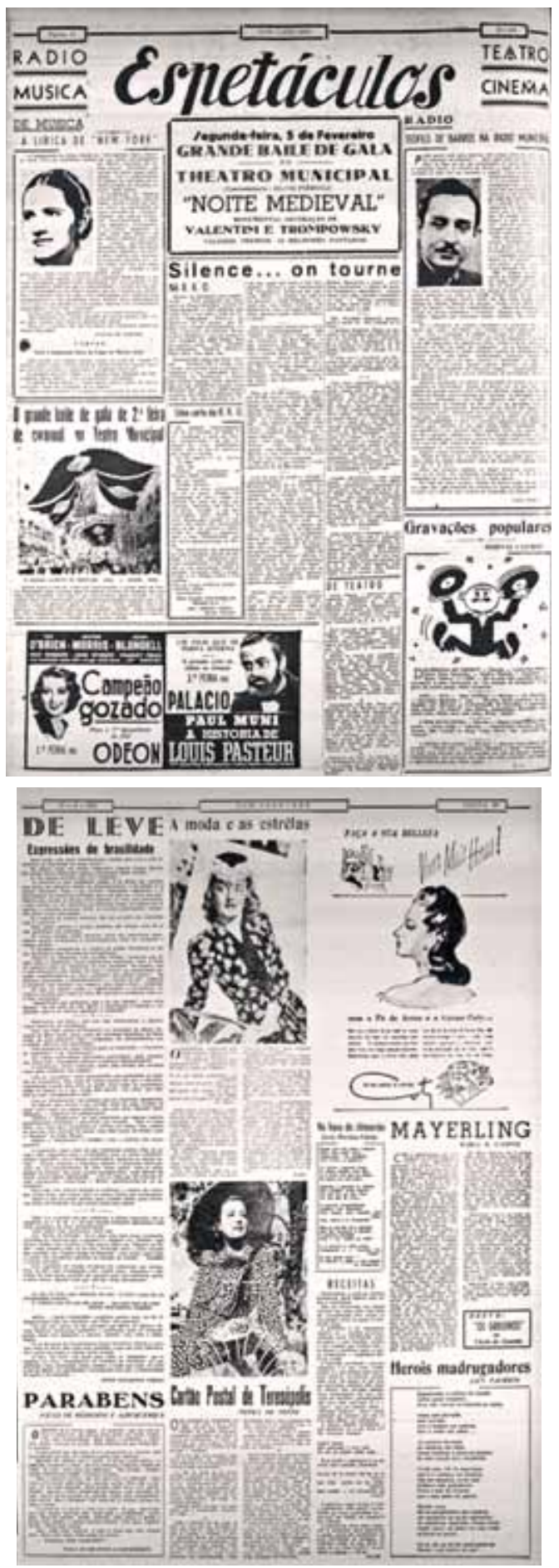

Figuras 5 e 6. Exemplos de página encimadas por rubricas identificadoras: "Para você" (29 jan. 1940) e "Espetáculos" (15 maio 1941). 

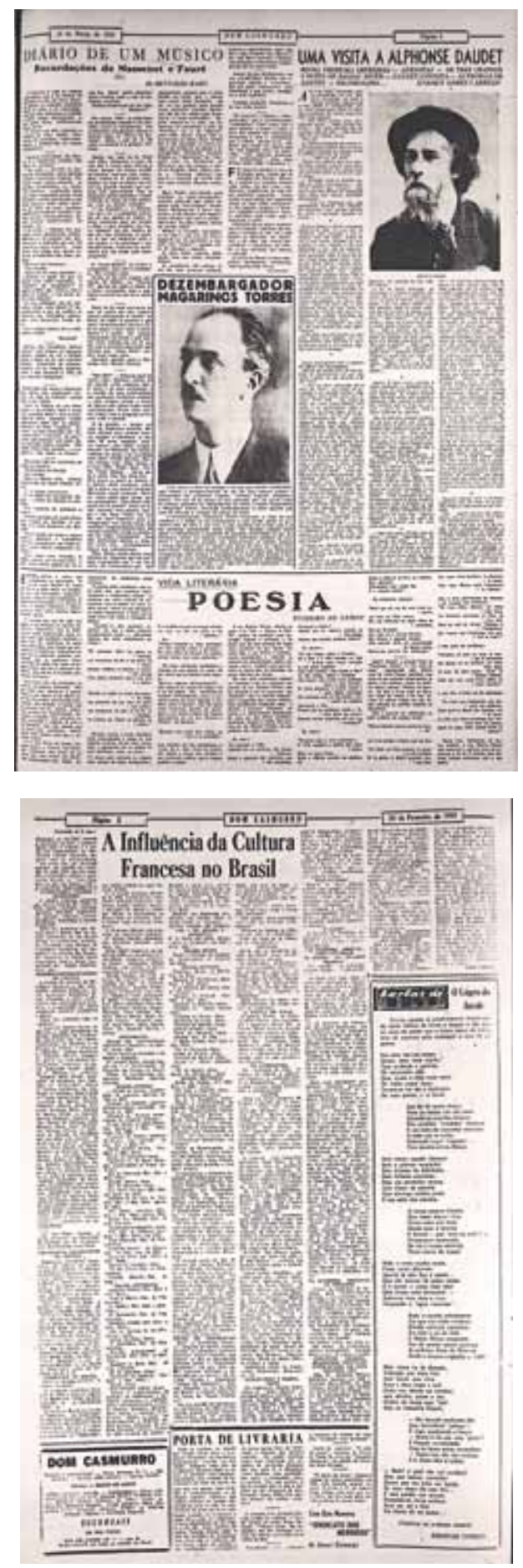

Figuras 7 e 8. Exemplo de páginas sem as rubricas, exemplares de 13 mar. 1943 e 24 fev. 1945. 

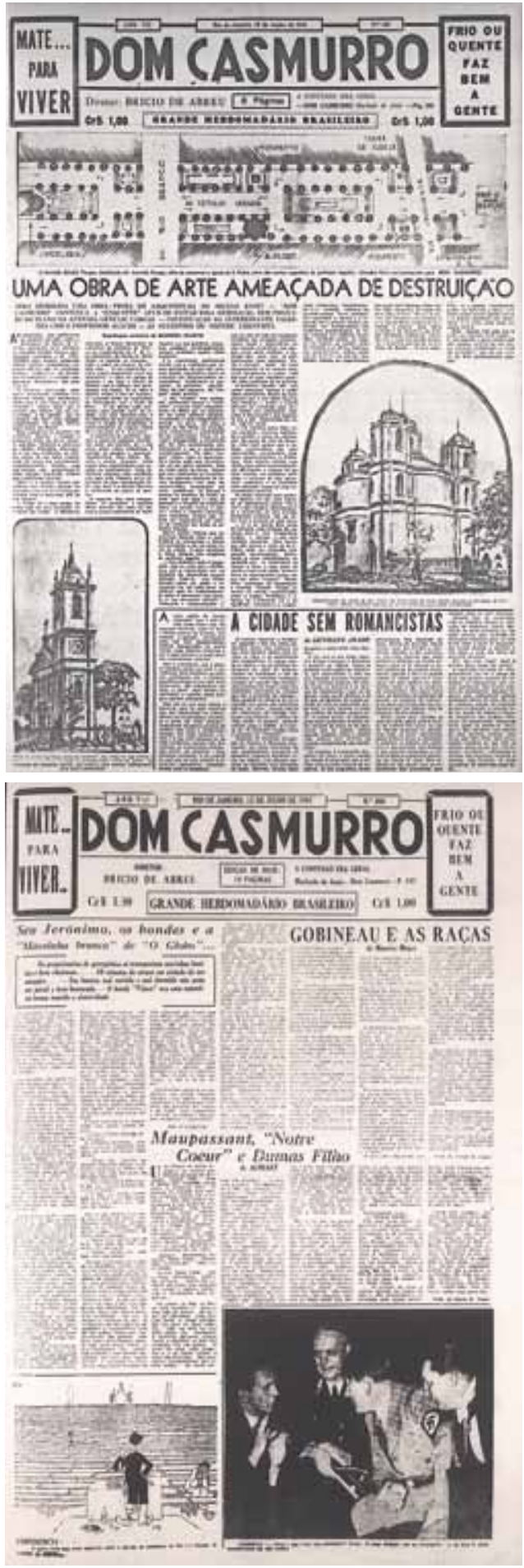

Figuras 9 e 10. Exemplos de capas, 12 jun. 1943 e 15 set. 1944. 